\title{
PERSEPSI DAN PARTISIPASI MASYARAKAT DALAM UPAYA \\ REHABILITASI HUTAN DAN LAHAN \\ DI KABUPATEN BOLAANG MONGONDOW TIMUR
}

\section{PERCEPTION AND PARTICIPATION OF COMMUNITY IN EFFORT OF LAND AND FOREST REHABILITION IN EAST BOLAANG MONGONDOW DISTRICT}

\author{
Frida Mamuko'), H. Walangitan²) dan W. Tilaar') \\ 1)Dinas Kehutanan dan Perkebunan Pemkab. Bolaang Mongondow Timur \\ 2)Fakultas Pertanian Unsrat Manado
}

\begin{abstract}
ABSTRAC
The aim of this research are; to describe community perception and participation; analyze social and economy factors that influence perception and participation of community of the land and forest rehabilitation programme in East Bolaang Mongondow District. This research was conducted using survay analysis approach. Furthermore,analysis of perception and participation using Likert Scale. Survay was conducted to 102 respondents in 3 Sub Districts inculuding 7 villages in East Bolaang Mongondow District. The results of the research shows that perception level of respondents to the forrest and its function are $48 \%$ highly perception, medium perception $45.1 \%$, and $6.9 \%$ low perception. Furthermore, perception level of respondents to the land and rehabilitation programme are $51 \%$ highly perception, medium perception $35 \%$, and $10 \%$ respondents low perception. Rank Spearman Correlation analysis shows that perception level influenced by the education level. Analysis results of the participation level shows that $36.27 \%$ highly perception, $34.31 \%$ medium perception, and $29.41 \%$ low perception. Rank Spearman Correlation analysis also shows that participation level influenced by the education level of the respondents.
\end{abstract}

Keywords : perception, participation, land rehabilitation

\begin{abstract}
ABSTRAK
Penelitian ini bertujuan untuk mendeskripsikan Persepsi dan Partisipasi masyarakat dalam program rehabilitasi hutan dan lahan serta menganalisis faktor-faktor sosial ekonomi yang mempengaruhi persepsi dan partisipasi masyarakat dalam program rehabilitasi hutan dan lahan di Kabupaten Bolaang Mongondow Timur. Penelitian dilakukan dengan metode pendekatan survey. Selanjutnya analisis persepsi dan partisipasi menggunakan skala Likert. Survei dilakukan kepada 102 responden yang tersebar di 3 Kecamatan meliputi 7 desa di Kabupaten Bolaang Mongondow Timur. Hasil penelitian menunjukan tingkat persepsi responden terhadap hutan dan fungsinya persepsi tinggi sebesar tinggi $48 \%$, sedang $45,1 \%$ dan persepsi rendah $6,9 \%$. Selanjutnya tingkat persepsi terhadap program Rehabilitasi Hutan dan Lahan terbagi atas tinggi $51 \%$, sedang $35 \%$ dan rendah $10 \%$. Corelasi Rank Speaman menunjukan bahwa tingkat persepsi dipengaruhi oleh faktor tingkat pendidikan. Hasil analisis partisipasi menunjukkan bahwa $36,27 \%$ tergolong partisipasi tinggi, sedang $34,31 \%$ dan $29,41 \%$ rendah. Corelasi Rank Spearman menunjukan partisipasi dipengaruhi juga oleh faktor tingkat pendidikan.

Kata kunci: persepsi, partisipasi, rehabilitasi lahan
\end{abstract}




\section{PENDAHULUAN}

\section{Latar Belakang}

Sumberdaya lahan memiliki peranan vital karena merupakan aset kunci bagi suatu negara, dimana kondisi kualitas dan kuantitas sumberdaya lahan tersebut menjadi penentu kelangsungan hidup generasi yang akan datang. Menyadari hal tersebut Pemerintah Republik Indonesia terus mengupayakan konservasi tanah dan air sebagai program penting dalam pembangunan agar sumber daya lahan tersebut tidak mengalami degradasi yang pada akhirnya berdampak negatif bagi pembangunan bangsa. Kebijakan pengendalian laju degradasi lahan di Indonesia diupayakan pemerintah melalui program Rehabilitasi dan Peningkatan Kualitas Sumber Daya Alam dan Lingkungan Hidup, yang bertujuan untuk mengatasi dan mengantisipasi degradasi sumber daya lahan melalui upaya rehabilitasi lahan dan konservasi tanah secara teknis dan biologis serta pengaturan dan pengendalian tata ruang.

Laju Kerusakan hutan dan lahan di Kabupaten Bolaang Mongondow Timur tergolong cukup tinggi. Menurut hasil review data dan peta lahan kritis Provinsi Sulawesi Utara Tahun 2013 luas lahan dengan kategori tidak kritis seluas $\pm 41,86 \mathrm{Ha}$, Potensial kritis $32.240 .84 \mathrm{Ha}$, Agak kritis $33,239.94$ $\mathrm{Ha}$, Kritis 20,595.69 Ha dan kategori sangat kritis seluas $\pm 2,347.04 \mathrm{Ha}$. Luas lahan kritis diperkirakan bertambah, penyebab pertambahan luas lahan kritis tersebut diantaranya disebabkan oleh aktifitas perluasan pemukiman, pertambangan di luar dan dalam kawasan hutan, perladangan serta kerusakan vegetasi akibat bencana alam.

Sejalan dengan kebijakan nasional, Pemerintah Kabupaten Bolaang Mongondow Timur menempatkan kegiatan Rehabilitasi Hutan dan Lahan (RHL) sebagai salah satu program pembangunan daerah. Program Pemerintah yang telah melakukan berbagai upaya untuk mengurangi laju lahan kritis diantaranya adalah Rehabilitasi Hutan dan Lahan (RHL) yang program-program di dalamnya meliputi : Hutan Desa (HD) yang saat ini sedang difasilitasi, Hutan Tanaman Rakyat (HTR) sesuai dengan pencanangan seluas \pm 2.225 ha yang ada di Kabupaten Bolaang mongondow Timur yang terdiri dari 11 Kelompok Tani Hutan (KTH), Hutan Kemasyarakatan $(\mathrm{HKm})$ yang masih dalam proses namun lokasi Hkm sudah dicanangkan dan Program Kebun Bibit Rakyat (KBR) yang sudah berlangsung sejak Tahun 2011 dengan Jumlah KTH sebanyak 57 KTH. Berdasarkan data implementasi program dan kegiatan RHL di Kabupaten Bolaang Mongondow Timur (Boltim) sebagai program Dinas Kehutanan telah dilaksanakan sejak Kabupaten Boltim ini berdiri seluas \pm 500 ha baik dalam kawasan hutan lindung maupun kawasan hutan produksi.

Keberhasilan program rehabilitasi hutan dan lahan sebagaimana diuraikan di atas sangat dipengaruhi oleh banyak faktor, baik faktor teknis, kelembagaan maupun sosial ekonomi masyarakat sasaran kegiatan. Dari aspek teknis kendala yang dihadapi diantaranya kondisi iklim, tanah dan aspek ekologis lainnya, sedangkan dari aspek kelembagaan sering diperhadapkan pada hambatan pelaksanaan kegiatan karena mengikuti prosedur keproyekan. Dari aspek sosial ekonomi keberhasilan program dipengaruhi oleh persepsi dan perilaku sebagai faktor yang mendorong tingkat partisipasi masyarakat. Persepsi dan partisipasi masyarakat merupakan faktor kunci dalam mendukung dan menjamin keberhasilan program RHL. Persepsi berkaitan dengan pemahamannya terhadap program sedangkan partisipasi sebagai wujud tindakan sukarela terlibat secara aktif dalam program RHL. Walangitan (2012) menyatakan bahwa persepsi yang tinggi terhadap pentingnya konservasi tanah dan air berkorelasi positif dengan wujud keragaan usahatani konservasi yang diterapkan. Dari uraian tersebut diatas terlihat bahwa faktor persepsi dan tingkat partisipasi akan menentukan keberhasilan program.

Berdasarkan masalah tersebut di atas maka dilakukan penelitian mengenai persepsi dan partisipasi masyarakat akan program rehabilitasi hutan dan lahan serta faktor-faktor sosial ekonomi yang dapat mempengaruhi persepsi dan partisipasi masyarakat tersebut.

\section{METODE PENELITIAN}

Metode yang digunakan dalam penelitian ini adalah metode kualitatif karena objek dari penelitian ini merupakan objek sosial. Teknik pemilihan 
sampel yang digunakan pada penelitian ini adalah sampel dipilih secara sengaja (purposive sampling) yakni penduduk laki-laki atau kepala keluarga (KK). Pengambilan sampel secara purposive ini dengan pertimbangan lokasi pelaksanaan program RHL terdapat di daerah-daerah yang relatif jauh dari lokasi pemukiman sehingga yang berhubungan dengan kegiatan tersebut adalah para penduduk laki-laki, selain itu pemilihan laki-laki dewasa dengan harapan mereka telah memiliki pengetahuan dan persepi yang benar mengenai rehabilitasi hutan dan memiliki kematangan dalam mengambil keputusan serta berpikir positif dalam bertindak.

Penentuan jumlah sampel ditetapkan dengan rumus sebagai berikut (Parel, et. al., 1973 dalam Dirjen RLL, 1998):

$$
n=\frac{N z^{2} p(1-p)}{N d^{2}+Z^{2}(1-p)}
$$

Dimana,

$\mathrm{n}=$ jumlah responden yang akan diambil

$\mathrm{N}=$ jumlah seluruh unit populasi $(\mathrm{Nh} 1+\mathrm{Nh} 2+\mathrm{Nh} 3=$ Jumlah petani pada masing-masing desa)

$z=$ nilai variabel random (dikehendaki signifinance level 95\%, maka $z=1,960$ )

$d=$ maksimum eror yang masih diterima $10 \%$, maka $\mathrm{d}=0,10$

$p=$ Proporsi Jumlah responden pada masing-masing desa ditetapkan dengan rumus sebagai berikut:

dimana :

$$
\mathrm{n} 1=\frac{N h 1}{N} \times \mathrm{n}
$$

$\mathrm{n}=$ Jumlah sampel yang diambil pada desa ke 1

Tabel 1. Jumlah Responden menurut Kecamatan dan Desa

(Table 1. Total of Respondents by District and Village)

\begin{tabular}{cccc}
\hline No & Kecamatan & Desa & Jumlah Responden \\
\hline 1 & Kotabunan & Bukaka & 15 \\
& & Kotabunan & 15 \\
\multirow{2}{*}{2} & \multirow{3}{*}{ Tutuyan } & Bulawan & 15 \\
& & Tutuyan & 15 \\
3 & \multirow{2}{*}{ Nuangan } & Dodap & 15 \\
& & Atoga & 15 \\
& & Idumun & 12 \\
\hline & & & 102 \\
\hline
\end{tabular}

Sumber: Data hasil olahan (2015)
Nh1 = Jumlah unit populasi pada desa 1

$\mathrm{N}=$ Jumlah seluruh sampel yang diambil berdasarkan rumus 1

Selanjutnya jumlah sampel untuk desa 2 dan 3 dihitung sebagai berikut :

$$
N_{2}=\frac{N h 2}{N} \times n ; N_{3}=\frac{N H 3}{N} \times n
$$

Berdasarkan persamaan di atas jumlah responden menurut kecamatan dan desa di sajikan pada Tabel 1.

Analisis persepsi dan partisipasi masyarakat terhadap program RHL dilakukan dengan pendekatan kuantitatif dengan menggunakan Skala Likert. Selanjutnya untuk mengukur hubungan antara faktor sosial ekonomi responden dengan tingkat persepsi dan partisipasi dilakukan dengan analisis Rank Spearman. Variabel tergantung berupa partisipasi masyarakat dalam pelaksanaan rehabilitasi hutan dan lahan, dan variabel bebas yang terdiri dari umur, tingkat pendidikan, pekerjaan, pendapatan, status sosial dan persepsi tentang rehabilitasi hutan.

Analisis data meliputi: (1) analisis instrumen bertujuan untuk mengukur validitas dengan menggunakan persamaan berikut :

Analisis Validitas intrumen (Siregar, 2010)

Dimana :

$$
\mathrm{r}=\frac{\left.n \sum X Y\right)-\left(\sum X Y\right)\left(\sum X Y\right)}{\sqrt{n\left(\sum X^{2}\right)-\left(\sum X\right)^{2} \ln \left(\sum Y^{2}\right)-\left(\sum Y\right)^{2}}}
$$

$\mathrm{n}=$ Jumlah responden

$\mathrm{x}=$ Skor Variabel

$y=$ Skor Total variabel untuk responden $n$ 
Analisis korelasi faktor sosial ekonomi yang mempengaruhi persepsi dan partisipasi

$$
r s=1-\frac{6 \sum D^{2}}{n\left(n^{2}-1\right)}
$$

dimana: $D^{2}$ adalah perkalian perbedaan antara dua set nilai yang sudah diurutkan; $n$ adalah jumlah kasus atau sampel yang diurutkan. Analisis korelasi antara faktor sosial ekonomi dengan persepsi dan partisipasi menggunakan metode pendekatan non parametric Corelasi Rank Spearman sebagai berkut: Rumus corelasi dan uji $\mathrm{t}$

$\mathrm{t}=\mathrm{rs} \frac{\sqrt{n-2}}{1-r s^{2}}$

Selanjutnya untuk analisis data dilakukan dengan menggunakan persamaan-persamaan yang dilakukan dengan bantuan program Statistical Pakage For Social Science (SPSS) versi 18.

\section{HASIL DAN PEMBAHASAN}

\section{Deskripsi Karakteristik Sosial Ekonomi Responden}

Hasil survei karakteristik sosial ekonomi rumah tangga sebanyak 102 responden pada 7 desa di tiga wilayah kecamatan secara rinci disajikan pada Tabel 1. Selanjutnya berdasarkan data Tabel 1 tersebut dilakukan analisis deskriptif untuk menggambarkan kondisi sosial ekonomi responden sebagaimana disajikan pada Tabel 2 .

Analisis statistik deskriptif yang disajikan pada Tabel 2, diuraikan sebagai berikut:
Umur

Umur responden (UMR). Umur responden merupakan faktor yang berpengaruh dalam pengambilan keputusan. Umur berkaitan dengan pengalaman yang akan membentuk persepsi dan perilaku seseorang. Berdasarkan data yang disajikan pada Tabel 2, terlihat bahwa umur responden terendah adalah 24 tahun dan tertinggi adalah 72 tahun. Deskripsi frekwensi responden menurut umur disajikan pada Gambar grafik 1. Dari grafik tersebut terlihat bahwa kelas umur tertinggi responden antara 41-50 tahun $(28.6 \%)$ diikuti kelas umur $51-60$ tahun (15.4\%). Sebagai umur responden tersebut tergolong pada kategori tenaga kerja pertanian dewasa. Sedangkan persentase responden yang tergolong tenaga kerja muda yaitu kelompok umur 20-40 tahun (40.7\%). Suatu hal yang menarik dari data hasil survei bahwa terdapat $8.8 \%$ petani yang sudah tergolong pada usia lanjut yaitu berumur $>$ 61-70 tahun namun masih beraktivitas dalam usahatani. Hal ini menggambarkan bertambahnya umur harapan hidup di wilayah studi.

\section{Pendidikan}

Tingkat pendidikan petani berpengaruh pada kemampuan untuk mendapatkan dan menggunakan informasi yang berhubungan dengan rehabilitasi hutan dan lahan dalam aktifitas usahataninya.

Tabel 2. Deskripsi Sosial Ekonomi Rumah Tangga Responden

(Table 2. Social Economy Household Respondent Description)

\begin{tabular}{|c|c|c|c|c|c|c|}
\hline \multirow{2}{*}{ Variable } & \multirow{2}{*}{$\mathrm{N}$} & \multirow[t]{2}{*}{ Nilai sedang } & & \multirow[t]{2}{*}{ Nilai Max } & \multicolumn{2}{|r|}{ Mean } \\
\hline & & & Nilai Min & & Statistic & Std. Error \\
\hline UMR & 102 & 48.00 & 24.00 & 72.00 & 43.2255 & 1.13177 \\
\hline LLH & 102 & 8.00 & .00 & 8.00 & 1.2941 & .10596 \\
\hline PDK & 102 & 3.00 & 1.00 & 4.00 & 1.9510 & .09282 \\
\hline PPB & 102 & 3.00 & 12.43 & 15.42 & 13.8402 & .05637 \\
\hline JTR & 102 & 9.00 & .00 & 9.00 & 3.2843 & .17029 \\
\hline PER & 102 & 24.00 & 16.00 & 40.00 & 32.4902 & .47898 \\
\hline Jumlah & 102 & & & & & \\
\hline
\end{tabular}

Sumber : Data primer hasil olahan (2015) 


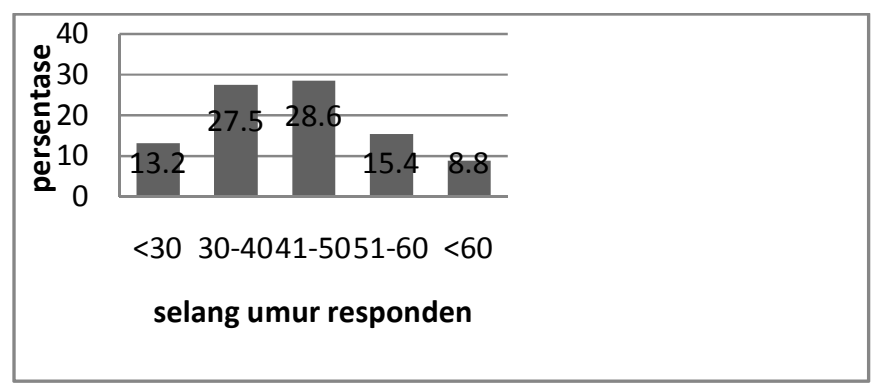

Gambar 1. Grafik Persentasi Sebaran Umur Responden

(Figure 1. Graph Percentage Distribution of the Respondens Age)

Tabel 3. Karakteristik Tingkat Pendidikan Responden

(Table 3 Respondent Education Stage Charateristic)

\begin{tabular}{lcc}
\hline \multicolumn{1}{c}{ Kriteria Tingkat Pendidikan } & Jumlah & $\%$ \\
\hline Tamat Akademi/PT & 3 & 2,94 \\
Tidak/Tamat SD & 44 & 43,14 \\
Tidak/Tamat SMA & 30 & 29,41 \\
Tidak/Tamat SMP & 25 & 24,51 \\
\hline
\end{tabular}

Sumber : Data primer hasil olahan (2015)

Jumlah responden menurut lamanya menempuh pendidikan formal disajikan pada Tabel 3. Dari Tabel 3 menunjukkan bahwa sebanyak 43,14\% responden menempuh pendidikan selama kurang 6 tahun atau berpendidikan sampai tingkat Sekolah Dasar (SD). 24,51\% responden menempuh pendidikan lebih dari 6 tahun hingga 12 tahun, sedangkan responden yang menempuh pendidikan lebih dari 12 tahun atau lulus sekolah menengah atas (SMA) sebanyak $29,41 \%$ bahkan terdapat 3 (tiga) responden menempuh pendidikan hingga lulus perguruan tinggi. Dengan demikian dapat dikatakan bahwa sebagian besar responden di wilayah studi memiliki tingkat pendidikan yang tergolong kategori rendah.

Pendidikan sangat penting bagi kehidupan masyarakat. Karena tingkat pendidikan yang mereka peroleh dapat membantu untuk mendapatkan pekerjaan yang lebih baik dan mempengaruhi pola pikir mereka terhadap segala perubahan yang terjadi di lingkungan sekitarnya termasuk dalam kegiatan rehabilitasi hutan dan lahan. Akan tetapi pada Kenyataannya tingkat pendidikan masyarakat khususnya responden masih rendah. Namun demikian status pendidikan bukan faktor tunggal yang berperan dalam pembentukan prilaku responden terhadap program rehabilitasi hutan dan lahan.

\section{Luas Kepemilikan Lahan (LLH)}

Luas penguasaan lahan baik lahan sawah maupun lahan kering sebagai gambaran potensi aset rumah tangga tani dan sebagai indikator sosial ekonomi yang penting bagi masyarakat pedesan. Dari data rekapitulasi responden dapat diketahui bahwa; luas kepemilikan lahan terbesar adalah 4 ha, dan untuk kepemilikan lahan terkecil adalah 0,25 ha. Karakreristik kepemilikan lahan responden di tiga kecamatan lokasi peneltian disajikan pada Tabel 4.

Dari Tabel 4 dilihat bahwa sebagian besar responden memiliki lahan di atas 0.6 ha yaitu sebesar $59.8 \%$ dan yang memiliki lahan di bawah 0.5 ha adalah $6.9 \%$ bahkan ada sembilan responden atau $8.8 \%$ yang tidak memiliki lahan garapan.

\section{Penghasilan Per Bulan (PPB)}

Tingkat pendapatan usaha tani ditentukan oleh jenis tanaman dan luas areal yang diusahakan. Hasil survei menunjukkan bahwa $59.8 \%$ responden mengusahakan lahan dengan luas $(0.6=1 \mathrm{ha})$, $14.7 \%$ mengusahakan lahan dengan luas $1-2$ ha dan $6.9 \%$ mengusahakan lahan dengan luas kurang dari 0.5 ha.

Hasil wawancara diperoleh informasi bahwa sekitar $60 \%$ petani menanam jagung dan palawija 
sebagai pilihan utama dan hanya sekitar $40 \%$ jenis tanaman perkebunan. Dari hasil survei perkiraan pendapatan rumah tangga tani dari usaha tani tanaman semusim dan tanaman tahunan disajikan pada Tabel 5 .

\section{Jumlah Tanggungan Rumah Tangga (JTR)}

Jumlah Tanggungan Rumah Tangga (JTR) adalah jumlah anggota rumah tangga yang belum bekerja secara produktif dan mandiri terutama dalam status bersekolah dan orang tua lanjut. Walaupun secara sosial masih menggantungkan hidup pada orang tua terutama untuk kebutuhan makanan, namun jumlah anggota keluarga merupakan gambaran potensi tenaga kerja dalam usaha tani keluarga. Kisaran jumlah tanggungan keluarga responden di lokasi penelitian adalah 1 sampai dengan 9 orang. Dari data karakteristik responden yang terlampir yang menggambarkan bahwa JTR terbanyak yaitu 8 orang dan terkecil adalah 1 orang.

Responden di lokasi penelitian sebagian besar memiliki JTR pada kisaran $2-4$ orang. Tabel 6 dapat menunjukkan karakteristik JTR responden di lokasi penelitian.

\section{Analisis Persepsi \\ Persepsi Terhadap Hutan dan Fungsinya}

Persepsi adalah proses dalam memahami lingkungan yang melibatkan pengorganisasian dan penafsiran sebagai rangsangan dalam suatu pengalaman psikologis. Sedangkan sikap berhubungan dengan pikiran, penilaian tentang masalah dan kebijakan yang diukur dengan pertanyaan (Silalahi, 2010).

Analisis persepsi responden petani mengenai persepsi terhadap hutan dan fungsinya serta hubungannya dengan pelestarian sumber daya alam dilakukan dengan menggunakan metode skala Likert. Skala Likert digunakan dengan skala 1 (sangat rendah/sangat tidak setuju dengan pernyataan) 2, 3, , dan 4 (sangat tinggi/sangat setuju dengan pernyataan). Pengukuran persepsi dijabarkan konsep pengetahuan (kognitif) dan sikap (afektif) dalam konteks pengetahuan tentang hutan, cara dan kesediaan menjaga kelestariannya serta tanggung jawab berpartisipasi dalam mencegah agar tidak terjadi erosi.

Tabel 4. Luas Kepemilikan Lahan Responden

(Table 4. Respondent Width Land Property)

\begin{tabular}{lcc}
\hline \multicolumn{1}{c}{ Luas Lahan $(\mathrm{Ha})$} & Jumlah Responden (org) & Presentase $(\%)$ \\
\hline Tidak ada lahan & 9 & 8.8 \\
$<=0.5$ & 7 & 6.9 \\
$0.6-1$ & 61 & 59.8 \\
$1.0-2.0$ & 15 & 14.7 \\
$2.1-3.1$ & 7 & 6.9 \\
$>3,2$ & 3 & 2.9 \\
\hline Total & 102 & 100 \\
\hline
\end{tabular}

Sumber: Rekapitulasi hasil survei

Tabel 5. Hasil Survey Usaha Pendapatan Petani Tanaman Semusim dan Tanaman Tahunan.

(Table 5. Survey of Income Effort Farmer Season Plants and Year Plants Result)

\begin{tabular}{lc}
\hline \multicolumn{1}{c}{ Kisaran Pendapatan Per Bulan } & Presentase Responden (\%) \\
\hline < Rp 500.000 & 3.9 \\
$\geq$ Rp. $500.000-1.000 .000$ & 58,8 \\
> Rp. $1.000 .000-2.000 .000$ & 30.4 \\
> Rp. $2.000 .000-3.000 .000$ & 4.9 \\
> Rp. 3.000 .000 & 2 \\
\hline
\end{tabular}

Sumber: Rekapitulasi hasil survei (2015) 
Tabel 6. Jumlah Tanggungan Keluarga Responden

(Table 6. Respondent Family Total Responsibility)

\begin{tabular}{ccc}
\hline Jumlah Tanggungan Rumah Tangga (Org) & Jumlah Responden (Org) & Presentase (\%) \\
\hline $0-2$ & 37 & 36.3 \\
$3-4$ & 49 & 48.0 \\
$5-6$ & 8 & 7.8 \\
$>6$ & 8 & 7.8 \\
Jumlah & 102 & 100 \\
\hline
\end{tabular}

Sumber: Rekapitulasi hasil survei (2015)

Hasil uji reliabilitas instrument quisioner yang digunakan diperoleh nilai Apha Cronbach0.78, yang berarti dapat dipercaya dengan kategori cukup tinggi. Sedangkan uji validitas quisioner untuk mengetahui sejauh mana skor atau nilai atau ukuran yang diperoleh benar-benar menyatakan hasil pengukuran atau pengamatan yang ingin diukur (Siregar, 2010). Hasil uji validitas menunjukkan bahwa semua item pertanyaan yang diajukan valid dengan demikian instrumen yang digunakan layak .

Hasil rekapitulasi nilai persepsi setiap responden selanjutnya dibuat kategori, dimana nilai tertinggi adalah 40 dan nilai terendah 16. Hasil pengurangan antara skor tertinggi dan terendah tersebut dibagi dalam tiga kelas dengan rentang nilai masingmasing dengan menggunakan persamaan di atas. Berdasarkan persamaan tersebut diperoleh kategori tingkat persepsi sebagai berikut: persepsi tinggi dengan rentang 32-40, tingkat persepsi sedang dengan rentang nilai 24-31 dan tingkat persepsi rendah dengan nilai $16-23$.

Hasil analisis frekwensi responden menurut kategori tersebut disajikan pada Tabel 7 .

Dari Tabel 7 terlihat bahwa responden yang memiliki persepsi kategori tinggi sebesar $48 \%$, kategori sedang $45,1 \%$ dan persepsi kategori rendah sebesar $6,9 \%$.

Persepsi tinggi memiliki arti bahwa responden memiliki pemahaman yang baik terhadap hutan dan fungsinya, mengaplikasikannya dalam sistem usahatani serta bersedia berpartisipasi dalam menjaga dan melestarikan sumber daya alam untuk mempertahankan produktivitas lahan serta bertanggung jawab terhadap dampak erosi yang akan ditimbulkan.

Persepsi sedang memiliki arti bahwa responden kurang memahami tentang hutan dan man- faatnya, namun mempunyai kemauan untuk melakukan pencegahan terhadap kerusakan hutan serta bersedia berpartisipasi/mengupayakan pengendalian kerusakan sumber daya hutan yang ada di sekitarnya.

Persepsi rendah memiliki arti bahwa pemahaman terhadap upaya rehabilitasi hutan dan lahan masih terbatas, namun setuju ketika akan dilakukan tindakan pencegahan kerusakan hutan serta bersedia menegur apabila ada yang akan melakukan tindakan pengrusakan hutan dalam hal ini ada yang menebang pohon tanpa ijin, tidak memiliki pemahaman yang kuat arti pentingnya peningkatan kualitas sumber daya alam dan menganggap bahwa banjir dan tanah longsor diakibatkan hanya oleh faktor alam.

\section{Persepsi Masyarakat Terhadap Program Rehabilitasi Hutan dan Lahan (RHL) \\ Hasil uji reliabilitas instrument quisioner} yang digunakan untuk mengukur persepsi masyarakat terhadap program RHL diperoleh nilai Apha Cronbach0.85 yang berarti dapat dipercaya dengan kategori tinggi. Sedangkan uji validitas quisioner untuk mengetahui sejauh mana skor atau nilai atau ukuran yang diperoleh benar-benar menyatakan hasil pengukuran atau pengamatan yang ingin diukur (Siregar, 2010). Hasil uji validitas menunjukkan bahwa semua item pertanyaan yang diajukan valid dengan demikian instrumen yang digunakan layak.

Hasil rekapitulasi nilai persepsi setiap responden terhadap kegiatan RHL selanjutnya dibuat kategori, dimana nilai tertinggi adalah 55 dan nilai terendah 26. Hasil pengurangan antara skor tertinggi dan terendah tersebut dibagi dalam tiga kelas dengan rentang nilai masing-masing dengan menggunakan persamaandi atas. Berdasarkan persamaan 
tersebut diperoleh kategori tingkat persepsi sebagai berikut: persepsi tinggi dengan rentang 45-54, tingkat persepsi sedang dengan rentang nilai $36-44$ dan tingkat persepsi rendah dengan nilai 26-35.

Rehabilitasi hutan adalah upaya untuk memulihkan, mempertahankan, dan meningkatkan fungsi hutan dan lahan sehingga daya dukung, produktivitas dan peranannya dalam mendukung sistem penyanggah kehidupan tetap terjaga. Kegiatan rehabilitasi hutan dan lahan merupakan upaya strategis kebijakan prioritas pembangunan nasional.

Pengetahuan dan pemahaman masyarakat terhadap kegiatan rehabiliatsi dinilai cukup baik. Meskipun sebagain besar ada yang menyatakan tidak tahu arti dan makna dari kegiatan rehabilitasi tersebut, tetapi mereka sangat mengerti akan hak dan kewajibannya sebagai anggota masyarakat. Sebanyak $70 \%$ dari responden menyatakan tahu akan hak dan kewajibannya sedangkan $90 \%$ petani yang mengetahui hak dan kewajibannya. Adanya ketidaktahuan beberapa petani ini disebabkan karena jarangnya mereka untuk mengikuti pertemuan rutin yang dilakukan oleh anggota masyarakat selama ini. Selain itu beberapa responden sama sekali tidak mengetahui karena tidak pernah terlibat secara langsung dalam kegiatan rehabilitasi sehingga pemahaman mereka terhadap rehabilitasi tersebut sangat rendah.

\section{Hubungan Aspek Sosial Ekonomi dengan Persepsi}

Analisis korelasi Rank Spearman dilakukan untuk mengetahui faktor sosial ekonomi responden yang mempengaruhi tingkat persepsi terhadap hutan dan fungsinya. Hasil uji korelasi Rank Spearman disajikan pada Tabel 8.

Dari Tabel 8 menunjukkan bahwa terdapat faktor pendidikan responden berpengaruh secara signifikan. Sedangkan faktor sosial ekonomi lainnya tidak berpengaruh nyata.

Lamanya seseorang menempuh pendidikan formal menggambarkan tingkat pengetahuan serta wawasan termasuk pengetahuan hutan dan fungsinya. Menurut Akudugu, et. al. (2012) bahwa pengaruh positif lamanya pendidikan formal berhubungan dengan pembentukan pola pikir untuk menerima halhal logis dari lingkungan sekitarnya.

Tabel 7. Persentase Responden Menurut Kategori Tingkat Persepsi Terhadap Hutan dan Fungsinya

(Table 7. Respondent Perception Stage About Forest and its Function Categories Presentation)

\begin{tabular}{cccc}
\hline Rentang nilai & Kategori & Jumlah & $\%$ \\
\hline $32-40$ & Tinggi & 48 & 48.0 \\
$24-31$ & Sedang & 46 & 45.1 \\
$16-23$ & Rendah & 8 & 6.9 \\
\hline
\end{tabular}

Sumber: Hasil analisis (2015)

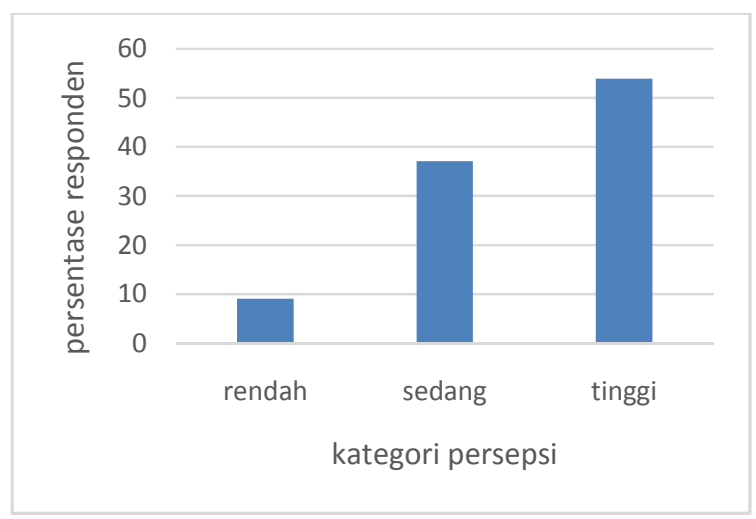

Gambar 2. Grafik Persentase Persepsi Responden

(Figure 2. Respondent Perception Presentation Graph) 
Tabel 8. Hasil Analisis Korelasi Faktor Sosial Ekonomi Dengan Tingkat Persepsi Responden terhadap Hutan dan Fungsinya

(Table 8. Social Economy Factor Correlation with Respondent Perception Stage to Forest and its Function Analysis Result)

\begin{tabular}{lccl}
\hline \multicolumn{1}{c}{ Variabel Sosial Ekonomi Petani } & Nilai rs & Sig. & \multicolumn{1}{c}{ Keterangan } \\
\hline UMR (tahun) & 0.076 & 0.121 & Tidak signifikan \\
LLH (ha) & 0.07 & 0.487 & Tidak signifikan \\
PDK (tahun) & $0.299^{*}$ & 0.002 & Signifikan \\
PPB(Rp/bulan) & 0.083 & 0.0409 & Signifikan \\
JTR (orang) & -0.080 & 0.425 & Tidak signifikan \\
\hline
\end{tabular}

Keterangan: ${ }^{*}$ Correlation is significant at the 0.05 level (1-tailed). $h$

Tabel 9. Hasil Analisis Korelasi Faktor Sosial Ekonomi Dengan Tingkat Persepsi Responden terhadap Program RHL

(Table 9. Social Economy Factor Correlation with Respondent Perception Stage to Land Rehabilition Program Analysis Result)

\begin{tabular}{lccl}
\hline \multicolumn{1}{c}{ Variabel Sosial Ekonomi Petani } & Koefisien Korelasi & Sig. & \multicolumn{1}{c}{ Keterangan } \\
\hline UMR (tahun) & 0.076 & 0.470 & Tidak signifikan \\
PDK (tahun) & $0.355^{*}$ & 0.001 & Signifikan \\
LLH (ha) & 0.018 & 0.122 & Tidak signifikan \\
PPB (Rp/bulan) & 0.102 & 0.340 & Tidak signifikan \\
JTR (orang) & 0.107 & 0.340 & Tidak signifikan \\
\hline
\end{tabular}

Keterangan: *Correlation is significant at the 0.05 level (1-tailed). ${ }^{*}$ Correlation is significant at the 0.01 level (1tailed). Listwise $N=102$

\section{Analisis Partisipasi}

\section{Partisipasi Masyarakat Terhadap Program} Rehabilitasi Hutan dan Lahan

Hasil uji reliabilitas instrument quisioner yang digunakan untuk mengukur partisipasi masyarakat terhadap program $\mathrm{RHL}$ diperoleh nilai Apha Cronbach0.93 yang berarti dapat dipercaya dengan kategori sangat tinggi. Sedangkan uji validitas quisioner untuk mengetahui sejauh mana skor atau nilai atau ukuran yang diperoleh benar-benar menyatakan hasil pengukuran atau pengamatan yang ingin diukur (Siregar, 2010). Hasil uji validitas menunjukkan bahwa semua item pertanyaan yang diajukan untuk mengukur partisipasi masyarakat ter- masuk kategori valid dengan demikian instrumen yang digunakan layak.

Hasil rekapitulasi nilai partisipasi setiap responden terhadap kegiatan program $\mathrm{RHL}$ selanjutnya dibuat kategori, dimana nilai tertinggi adalah 95 dan nilai terendah 32. Hasil pengurangan antara skor tertinggi dan terendah tersebut dibagi dalam tiga kelas dengan rentang nilai masing-masing dengan menggunakan persamaan di atas. Berdasarkan persamaan tersebut diperoleh kategori tingkat partisipasi sebagai berikut: tingkat persepsi tinggi dengan rentang 75-95, tingkat persepsi sedang dengan rentang nilai 54-74 dan tingkat persepsi rendah dengan nilai 3253. 
Tabel 10. Persentase Responden Menurut Kategori Tingkat Partisipasi terhadap Kegiatan RHL (Table 10. Respondent Perception Stage Categories to Land Rehabilitation Activity Presentation

\begin{tabular}{lccc}
\hline \multicolumn{1}{c}{ Kategori tingkat partisipasi } & Rentang nilai & Jumlah responden & Persentase (\%) \\
\hline Rendah & $32-54$ & 30 & 29.41 \\
Sedang & $55-74$ & 35 & 34.31 \\
Tinggi & $>75$ & 37 & 36.27 \\
Total & & 102 & \\
\hline
\end{tabular}

Sumber: Data hasil olahan (2015)

Partisipasi adalah hal turut berperan serta di suatu kegiatan, keikutsertaan, peran serta. Dengan demikian, maka dapatlah dikatakan bahwa partisipasi memiliki arti yang sama dengan peran serta responden didalam mengikuti setiap tahapan kegiatan dalam program rehabilitasi hutan dan lahan. Tahapan-tahapan kegiatan dalam program rehabilitasi hutan diawali dengan tahapan kegiatan perencanaan yang dilakukan lewat pertemuanpertemuan kelompok tani hutan untuk membahas rencana-rencana apa yang akan dilakukan dalam program rehabilitasi hutan. Peran serta juga harus diikuti dengan tindakan dan kesediaan dalam melakukan penanaman tanaman kayu-kayuan secara sukarela serta bersedia untuk memelihara tanaman yang ditanam tersebut.

Partisipasi berasal dari kata participation, yang berarti pengambilan bagian, pengikutsertaan. Partisipasi masyarakat berarti pengambilan bagian oleh masyarakat atau pengikutsertaan masyarakat dalam suatu kegiatan. Dalam praktek sehari-hari, partisipasi masyarakat dipahami atau ditafsirkan sebagai berikut: 1) Masyarakat bertanggung jawab hanya dalam pelaksanaan kegiatan-kegiatan. 2) Anggota masyarakat ikut menghadiri pertemuanpertemuan perencanaan, pelaksanaan dan pengkajian suatu kegiatan, namun sebatas sebagai pendengar. 3) Anggota masyarakat terlibat secara aktif dalam pengambilan keputusan tentang cara melaksanakan sebuah kegiatan dan ikut menyediakan bantuan serta bahan-bahan yang dibutuhkan dalam kegiatan tersebut. 4) Anggota masyarakat terlibat secara aktif dalam semua tahapan proses pengambilan keputusan, pengawasan serta monitoringnya.

Dengan pendekatan partisipasi, orangorang akan lebih bersemangat, lebih iklas dan lebih bertanggung jawab dalam melaksanakan suatu ke- giatan (Mu'arif, 2002). Kondisi kerusakan hutan dan lahan di Indonesia pada saat ini telah menjadi keprihatinan banyak pihak, baik secara nasional maupun internasional. Fenomena degradasi sumberdaya hutan dan lahan terus meningkat baik kualitas maupun kuantitasnya. Kerusakan hutan dan lahan tersebut telah mengakibatkan bencana alam yang besar, bahkan akhir-akhir ini kecenderungannya semakin meningkat, khususnya banjir, tanah longsor, dan kekeringan. Bencana tersebut telah menimbulkan kerugian nasional yang besar berupa kerusakan infrastruktur, berbagai aset pembangunan serta terganggunya tata kehidupan masyarakat. Penyebab utama terjadinya bencana tersebut adalah kerusakan lingkungan, terutama di wilayah hulu Daerah Aliran Sungai (DAS) sebagai daerah tangkapan air, kondisi di atas menumbuhkan kesadaran dari semua pihak untuk melakukan rehabilitasi hutan dan lahan yang rusak guna memperbaiki dan mengembalikan fungsi dan produktivitas sumber daya alam tersebut. Upaya tersebut juga dimaksudkan untuk menanggulangi bencana alam yang dilaksanakan secara terpadu, menyeluruh, dan terkoordinasi, dengan melibatkan pemerintah, lembaga swadaya masyarakat, petani, TNI dan POLRI (Warta Gerhan, 2006).

\section{Pengaruh Faktor Sosial Ekonomi terhadap Tingkat Partisipasi}

Analisis korelasi Rank Spearman digunakan untuk mengetahui faktor sosial ekonomi responden yang mempengaruhi tingkat partisipasi. Hasil uji korelasi Rank Spearman disajikan pada Tabel 11.

Dari tabel 11 menunjukkan bahwa faktor pendidikan responden yang berpengaruh secara signifikan terhadap tingkat partisipasi dengan nilai rs sebesar 0.29 dengan nilai Sig $0.003<0.05$. 
Tabel 11. Hasil Analisis Korelasi Faktor Sosial Ekonomi dengan Tingkat Partisipasi Responden terhadap Kegiatan RHL

(Table 11. Social Economy Factor Correlation with Respondent Perception Stage to Land Rehabilitation Analysis Result)

\begin{tabular}{llll}
\hline \multicolumn{1}{c}{ Variabel Sosial Ekonomi Petani } & \multicolumn{1}{c}{ Koefisien Korelasi } & \multicolumn{1}{c}{ Sig. } & \multicolumn{1}{c}{ Keterangan } \\
\hline UMR (Tahun) & 0.0378 & 0.0702 & Tidak signifikan \\
PDK (Tahun) & $0.290^{*}$ & 0.003 & Signifikan \\
LLH (ha) & 0.094 & 0.344 & Tidak signifikan \\
PPB (Rp/bulan) & 0.176 & 0.333 & Tidak signifikan \\
\hline
\end{tabular}

Partisipasi dapat dibagi atas berbagai macam bentuk. Partisipasi menurut Effendi (2002) terbagi atas partisipasi vertikal dan horizontal. Partisipasi vertikal karena bisa terjadi dalam bentuk kondisi tertentu masyarakat terlibat atau mengambil bagian dalam satu program pihak lain, dalam hubungan dimana masyarakat berada sebagai posisi bawahan. Sedangkan partisipasi horizontal, dimana masyarakat mempunyai prakarsa dimana setiap anggota masyarakat berpartisipasi horizontal satu dengan yang lainnya baik dalam melakukan usaha bersama, maupun dalam rangka melakukan kegiatan dengan pihak lain. Menurut Hardjasoemantri (1986) peran serta sebagai suatu proses komunikasi dua arah yang terus menerus untuk meningkatkan pengertian masyarakat atas suatu proses dimana masalah-masalah dan kebutuhan lingkungan sedang dianalisis oleh badan yang bertanggung jawab. Dan tujuan peran serta masyarakat adalah untuk menghasilkan masukan dan persepsi yang berguna bagi warga negara dan masyarakat yang berkepentingan dalam rangka meningkatkan kualitas pengambilan keputusan lingkungan. Pemberdayaan masyarakat dalam bentuk pelibatan masyarakat lokal dalam rangka pelestarian hutan merupakan hal yang mendasar dan positif, dimana kesadaran positif masyarakat dibangun dan dikembangkan sehingga masyarakat dapat melakukan kontrol sepenuhnya terhadap pengelolaan sumber daya hutan. Pada hakekatnya pemberdayaan masyarakat adalah suatu proses perubahan perilaku masyarakat sebagai pusat perhatian sekaligus dipandang dan diposisikan sebagai subyek bagi dirinya sendiri dalam proses pembangunan.

\section{KESIMPULAN DAN SARAN}

\section{Kesimpulan}

Berdasarkan penelitian yang telah dilakukan maka dapat ditarik kesimpulan bahwa tingkat persepsi masyarakat peserta program terhadap hutan dan fungsinya diperoleh nilai persepsi tergolong tinggi yaitu sebesar $48,0 \%$ yang diikuti oleh persepsi sedang $45,1 \%$ dan persepsi rendah $6,9 \%$. Sedangkan persepsi terhadap program rehabilitasi hutan dan lahan didapatkan sekitar $51 \%$ persepsi tinggi, $35 \%$ persepsi sedang dan 10\% persepsi rendah. Sedangkan tingkat partisipasi peserta program rehabilitasi hutan dan lahan didapatkan sebesar 36,27\% tergolong tinggi, $34,3 \%$ sedang dan 29,41 tergolong rendah

Faktor sosial ekonomi yang mempengaruhi persepsi terhadap hutan dan fungsinya serta persepsi terhadap program rehabilitasi hutan dan lahan dipengaruhi oleh tingkat pendidikan. Selanjutnya tingkat partisipasi juga dipengaruhi oleh tingkat pendidikan.

\section{Saran}

Perlu tindakan sosialisasi dalam rangka mengarahkan persepsi dan partisipasi masyarakat setempat agar secara holistik memahami makna pelestarian hutan yang dilakukan melalui program rehabilitasi hutan dan lahan. Dalam rangka sosialisasi ini, perlu juga dirumuskan tingkat kedalaman materi yang perlu disampaikan terkait dengan konteks kejadian di lapangan yang ada (keseimbangan teori dan praktek), misalnya dalam hal aktivitas pertanian yang sudah ada dapat dicontohkan lewat simulasi tentang kemampuan daya resap tanaman semusim dan tanaman tahunan sehingga masyarakat setempat mengetahui makna penurunan fungsi 
ekologis hutan. Kegiatan sosialisasi juga perlu mempertimbangkan keragaman kondisi sosial ekonomi warga, perlu ada pemilahan target group (kelompok sasaran) untuk dapat mewujudkan peran dari setiap individu atau kelompok individu yang bermukim di sekitar kawasan hutan.

Perlu adanya penguatan kapasitas lembaga baik lembaga pemerintah maupun lembaga masyarakat dalam rangka pelestarian hutan. Idealnya, lembaga masyarakat dalam hal ini Kelompok Tani Hutan (KTH) yang sudah terbentuk dapat digunakan sebagai wadah pemberdayaan masyarakat yang berlangsung secara kontinyu dalam rangka upaya rehabilitasi hutan dan lahan.

Berkaitan dengan tingkat persepsi dan partisipasi masyarakat terhadap proram rehabilitasi hutan dan lahan yang sangat dipengaruhi oleh tingkat pendidikan masyarakat maka perlu dilakukan penguatan kemampuan masyarakat melalui pendekatan pendidikan non formal seperti pelatihan, bimbingan teknis, magang, dan lainnya.

\section{DAFTAR PUSTAKA}

Akudugu, M. A., E. Guo, S.K. Dadzie. 2012. Adaption of Modern Agriculture Production Technologies by Farm Households In Ghana. What Factors Influence their Decisions? Journal of Biology, Agriculture and Healthcare www.iiste.org ISSN 22243208 (Paper) ISSN 225-093X 9Online) Vol 2, No. 3, 2012.

Derpatemen Kehutanan. 1998. Keputusan Direktorat Jenderal Reboisasi dan Rehabilitasi lahan No: 041/Kpts/V/1998/ tanggal 21 April 1998, tentang Pedoman penyusunan Rencana Teknik Lapangan Rehabilitasi Lahan dan Konservasi Tanah DAS. Dirjen Reboisasi dan Rehabilitasi Lahan Departemen Kehutanan.
Effendi, I. 2002. Analisis Persepsi Masyarakat Terhadap Taman Nasional Gunung Leuser (TNGL) di Desa Harapan Jaya.Kecamatan Lapan kabupaten Langkat Sumut. Tesis Program Pasca Sarjana USU. Medan.

Hardjasoementri, K. 1986. Aspek Hukum Peran serta Masyarakat Dalam Pengelolaan Lingkungan Hidup. Cetakan 3 Gadja Mada University Press. Yogyakarta.

Mu'arif, N. 2002. Memahami Partisipasi Masyarakat untuk Pemberdayaan. Departemen Kehutanan. Pusat Bina Penyuluh Kehutanan.

Siregar, S. 2010. Statistika Deskriptif untuk Penelitian. PT. RajaGrafindo Persada.

Silalahi, U. 2010. Metode Penelitian Sosial. PT. Refika Aditama.

Walangitan, H. D. 2012. Analisis Keragaan Sistem Usaha Tani Konservasi Pada Daerah Tangkapan Air Danau Tondano. Disertasi Universitas Brawijaya.

Warta Gerhan. 2006. Optimalisasi Peran Stekholder dalam Implementasi Gerhan di Lapangan. Direktorat Jenderal Rehabilitasi Lahan dan Perhutanan Sosial Departemen Kehutanan. Jakarta. 
